\title{
Multiple Principles AND THE OBLIGATION TO OBEY THE LAW
}

\author{
NKIRUKA AHIAUZU*
}

[George Klosko's multiple principle theory of political obligation is a recent formulation for the existence of a general obligation to obey the law. In the paper, I argue that the generality requirement of the obligation to obey the law gives rise to normative and factual problems of, respectively, motivation and comprehensiveness. I aim to show that whereas the multiple principle theory may solve the factual problem of the generality requirement, it does not solve its normative problem which I characterise as a first-personal implication of the question, 'why should I obey the law?']

\section{INTRODUCTION}

George Klosko’s multiple principle theory of political obligation is a recent formulation for the existence of a general obligation to obey the law. It consists of a combination of three principles - fair play, natural duty and the common good. It advances the notion that while separately these principles have not been successful in grounding a general obligation to obey the law, when combined, they are able to satisfy the requirements of such an obligation. These requirements are with relation to its generality and comprehensiveness. A significant aspect of this theory is that it tries to account for the wide range of services that the state provides.

\footnotetext{
${ }^{*}$ Lecturer in Law, University of Wales, Aberystwyth. Many thanks to the Oxford Jurisprudence Discussion group, Ben Saunders, the participants in Group 12 of the World Congress on Legal and Social Philosophy (2005) and Prof. George Klosko for their useful questions and arguments. I also thank the anonymous referee for the helpful comments and corrections given.
} 
In this essay, I argue that the generality requirement of the obligation to obey the law gives rise to normative and factual problems. I characterise its factual and normative problems as being comprehensiveness and motivation, respectively. I aim to show that whereas the multiple principle theory may solve the factual problem of the generality requirement, it does not solve its normative problem. I regard the normative problem of motivation as being one of the first-personal implications of the question 'why should I obey the law?'

In Section II, I begin by discussing the three concepts that Klosko employs to combine the principles into a single theory. They are cumulation, mutual support and overlap and I refer to them as the unification concepts of the multiple principle theory. I then discuss the three principles to show how the unification concepts work to combine them. I also here discuss the generality requirement with the aim of highlighting its normative and factual problems. I then show how comprehensiveness is the factual problem of the generality requirement and how though the multiple principle theory may satisfy it, does not address its normative problem. In Section III, I discuss the possible origins of the normative problem of motivation and in Section IV what it could imply for a hypothetical response to the practical question derived from the theory.

\section{UNIFYING PRINCIPLES}

The three principles namely, fair play, natural duty and the common good are combined in a single theory with the aim of satisfying the requirements of a 'general' obligation to obey the law. ${ }^{1}$ Klosko identifies these requirements as the '(1) ability to ground obligations of all or virtually all citizens and (2) to support a full range of governmental functions.' 2 The first requirement he calls the 'generality' requirement and the second the 'comprehensiveness' requirement. The generality requirement, which has also been referred to as the 'universality criterion" ${ }^{3}$, is a fundamental requirement with relation to the general obligation to obey the law. Those that doubt the existence of such an obligation generally do not disagree that a citizen may see himself as under a moral obligation to obey a particular law. ${ }^{4}$ What they contend with is whether the citizen has a 'general' obligation - one that applies to all or most laws, in all or most of the situations in which they arise. The project of those that claim that there indeed exists such an obligation is therefore to give accounts that can satisfy the universality requirement of obligation. ${ }^{5}$

\footnotetext{
${ }^{1}$ I intend to use the expressions 'obligation to obey the law' and 'political obligation' interchangeably though the former can be seen as only an aspect of the latter. However I also use the phrase 'natural duty' and do not intend the interchange to apply there. William EDMUNDSON, State of the Art: The Duty to Obey the Law, 10 LEGAL T. 217 (2004).

${ }^{2}$ George Klosko, Political Obligations (2005); George Klosko, Multiple Principles of Political Obligation, 32 POLITICAL T. 803 (2004).

${ }^{3}$ RUTH HIGGINS, THE MORAL LIMITS OF LAW 27 (2004). I intend to use both phrases interchangeably.

${ }^{4}$ An example of such an argument is given by Joseph Raz in THE AUTHORITY OF LAW: ESSAYS ON LAW AND MORALITY 233 (1979).

${ }^{5}$ I intend to use the terms 'duty' and 'obligation' interchangeably
} 
The 'comprehensiveness' requirement is so called because it requires that a theory of political obligation should cover the wide range of government functions. This is the main thrust of Klosko's theory. On his view, an adequate account of the obligation to obey the law should ground the different types of services that the state provides. A theory that only accounts for a certain type of state service and not others is not comprehensive and therefore inadequate. Klosko seeks therefore to combine the three principles (which separately can cater for different types of state functions), with the aim of constructing a single adequate theory. To combine the three principles, he devises three concepts namely, 'cumulation', 'mutual support' and 'overlap'. ${ }^{6}$ He describes them as follows:

First is what we call cumulation. Different principles can cover different services provided by the state, and so by combining principles, a larger range of state services can be accounted for. Second is what can be referred to as mutual support. In regard to certain state functions, if a given principle on its own cannot justify compliance, the problem might possibly be overcome by more than one principle working in tandem. The third way is simple overlap. The intuition here is that, while requirements to obey given laws could be relatively weak, these can be strengthened by support of additional principles. ${ }^{7}$

The three concepts identify the possible areas of limitation of the independent principles and determine how these principles can be effectively combined to successfully address those limitations. The 'cumulation' concept can be seen as enabling the principles to cover a wider range of state services. The concept of 'mutual support' addresses the limitations of the independent principles with relation to the justification of compliance to the law and the 'overlap' concept deals with the problem of the weakness of each principle when considered separately. These concepts thus represent the internal dynamics of unifying the three principles. I shall thus refer to them as the 'unification' concepts of the multiple principle theory.

As has been said, the three principles of the theory - fair play, natural duty and the common good are characterised by Klosko as dealing with different categories of state services. The fair play principle which was first articulated by H.L.A. Hart states that a cooperative enterprise gives rise to obligations among participants in the enterprise not to free-ride on the benefits received. ${ }^{8}$ Persons have a duty to contribute to the smooth running of an enterprise from which they have benefited

\footnotetext{
${ }^{6}$ KLOSKO, Political Obligations, supra note 2, at 101; Klosko, Multiple Principles, supra note 2, at 803.

${ }^{7}$ KLOSKO, Political Obligations, supra note 2, at 101; Klosko, Multiple Principles, supra note 2, at 803.

${ }^{8}$ HLA Hart, Are There Any Natural Rights?, 64 PHILOsophICAL REV., 185 (1955). For discussions specifically on free-riding see Richard Arneson, The Principles of Fairness and Free-Rider Problems, 92 Ethics 616 (1982); Garret Cullity, Moral Free Riding, 24 PhILOsophy P. A. 3 (1995); Phillip Petit, Free-Riding and Foul Dealing, 83 Journal P., 361 (1986); Jean Hampton, Free-Rider Problems in the Production of Collective Goods, 3 Economics P., 245, (1987); Lawrence Becker, The Free-Rider Problem, in THE LIMITS OF UTILITARIANISM, 217 (1982)
} 
by virtue of the efforts of fellow participants. ${ }^{9}$ For instance, where a group of neighbours set up a cooperative security scheme in which they each take turns to keep watch over the whole neighbourhood at night thereby ensuring that it is safe, each neighbour is under a duty to participate in the scheme since they are likely to benefit from the efforts of their fellow neighbours in keeping the neighbourhood safe. Deciding not to take their turn and keep watch would amount to a charge of free-riding on the benefit received. Rawls in his further development of the fair play principle puts it as follows,

Suppose there is a mutually beneficial and just scheme of social cooperation, and the advantages it yields can only be obtained if everyone, or nearly everyone cooperates. Suppose further that cooperation requires a certain sacrifice from each person, or at least involves a certain restriction of his liberty. Suppose finally that the benefits produced by cooperation are, up to a certain point, free: that is, the scheme of cooperation is unstable in the sense that if any one person know that all (or nearly all) of the others will continue to do their part, he will still be able to share a gain from the scheme even if he does not do his part. Under these conditions, a person who has accepted the benefits of the scheme is bound by a duty of fair play to do his part and not to take advantage of the free benefit by not cooperating. ${ }^{10}$

The fair play principle does not only imply a mutuality of restrictions on participants in the enterprise but also the notion of reciprocity. We see from Rawls' characterisation that the scheme of social cooperation may not necessarily be affected by the absence of the input of the particular member. However since by the nature of the scheme he is free to benefit from it, benefiting places him under a fair play obligation to reciprocate by cooperating. Also, where he can avoid benefiting from the scheme but chooses to benefit, he is under a duty of fair play. Klosko is of the view that the fair play principle satisfies the generality requirement ${ }^{11}$ to the extent that it covers what he calls 'presumptively beneficial' goods. These are goods that citizens cannot avoid taking advantage of. An example of this type of goods is physical security. The nature of the benefit is such that citizens may not be able to avoid benefiting from its provision by the state. Klosko gives conditions under which the principle can cover presumptively beneficial goods, most important of which is that it should be a benefit of such a nature that it is indispensable to the citizen's welfare. Being 'non-excludable' in this sense therefore means that the average citizen cannot be reasonably expected to carry on a worthwhile life without the good or service provided. The fair play principle can therefore apply to persons who cannot avoid benefiting from such state provided services. In this sense the fair play principle can said to be general. This is because the nature of presumptively beneficial goods is such that all or most persons will benefit from them and

\footnotetext{
${ }^{9}$ McDermott is of the interesting view that the presumed 'right' against free-riders is based on a general intuition. Daniel McDermott, Fair Play Obligations, 52 POLITICAL S., 216 (2004)

${ }^{10}$ John Rawls, Legal Obligation and the Duty of Fair Play in JOHN RAWLS: COLLECTED PAPERS, 122 (Samuel Freeman ed., 1999).

${ }^{11}$ KLOSKO, Political Obligations, supra note 2, at 102; Klosko, Multiple Principles, supra note 2, at 804.
} 
thereby be under the duty of fair play. The principle can also cover non-excludable goods but only to the extent that citizens choose to benefit from them. However, the element of choice is not similarly significant with relation to non-excludable goods and a fair play obligation can arise with relation to these goods.

However, although this is the strong point of the principle, it is also its weakness, in that though it can place persons under the duty not to free-ride with relation to nonexcludable goods, it cannot similarly do so with state services that do not have the feature of being presumptively beneficial. This is because where citizens choose not to take advantage of excludable goods, the duty will not arise. While there may be quite a number of presumptively beneficial state-provided goods that the citizen benefits from, there are also state-provided goods that he can live without. By virtue of this, Klosko is of the view that whereas the fair play principle may satisfy the requirement of generality it cannot be said to adequately address the comprehensiveness requirement. ${ }^{12}$ It does not cover the wide range of state services that do not have the feature of non-excludability. For the principle to be comprehensive all state-provided goods must be presumptively beneficial and this is not the case. State services include non-excludable as well as what he refers to as 'discretionary' goods which are goods that are not indispensable to the citizen. ${ }^{13}$ These may include symphonies, opera houses, public houses, public parks and museums. ${ }^{14}$ The limitation of the fair play principle, Klosko argues, is not resolved even by an indirect argument which could be that some non-excludable goods could rely on certain discretionary goods to function effectively. For instance national security requires roads to function. In this instance the fair play principle could cover the provision of roads not by virtue of its direct indispensability to the citizen but as a result of its direct indispensability to the provision of the non-excludable good of national security. This therefore could make it indispensable albeit indirectly, to the citizen. However, Klosko is of the view that even if a successful account of this complex relationship between presumptively beneficial goods and certain discretionary goods is given, it would still not render the fair play principle comprehensive enough to cover other not similarly related state services. ${ }^{15}$

The second principle in the theory is derived from the concept of natural duty. These duties are regarded as 'natural' because they apply to persons in the absence of any volitional undertaking. ${ }^{16}$ The duty of mutual aid as a derivative natural duty is therefore able to meet the generality requirement because unlike obligations, it is binding on persons regardless of whether or not it is voluntarily accepted. ${ }^{17} \mathrm{~A}$

\footnotetext{
${ }^{12}$ KLosko, Political Obligations, supra note 2, at 102; Klosko, Multiple Principles, supra note 2, at 804.

${ }^{13}$ KLOSKO, Political Obligations, supra note 2, at 101; Klosko, Multiple Principles, supra note 2, at 803. Also see George Klosko, The Obligation to Contribute to Discretionary Public Goods, 38 Political S. 196 (1990)

${ }^{14}$ KLOSKO, Political Obligations, supra note 2, at 104; Klosko, Multiple Principles, supra note 2, at 807.

${ }^{15}$ Klosko also includes within this group state services to other persons like the poor, handicapped and generally disadvantaged. KLOSKO, Political Obligations, supra note 2, at 105; Klosko, Multiple Principles, supra note 2, at 807.

${ }^{16}$ Klosko refers to Rawls at pages 114-15. KLOSKO, Political Obligations, supra note 2, at 105; Klosko, Multiple Principles, supra note 2, at 808.

${ }^{17}$ KLOSKO, Political Obligations, supra note 2, at 105; Klosko, Multiple Principles, supra note 2, at 808.
} 
species of this kind of duty is the duty to assist less fortunate persons in society. Unlike obligation, this duty is seen as a moral requirement binding on persons even though not voluntarily acquired. Klosko derives his characterisation of the principle from Rawls according to which we have natural political duties to contribute to the success of just institutions. ${ }^{18}$ However, for him these contributions should be made at as little personal expense as possible. Natural duties should only require minimal effort from the citizen. This, for Klosko is the limitation of the principle. While for him the fair play principle can ground welfare duties of citizens, it cannot account for what he refers to as the 'core obligations that are central to the workings of an acceptable state. ${ }^{, 19}$ Not all obligations in the state can be carried out with little cost to the citizen. Indeed some obligations require the citizen to make substantial sacrifices that may go beyond the requirements of natural duty. Klosko says,

Requirements to comply with just institutions so long as this is not costly to oneself would not ground obligations to pay burdensome taxes or to obey costly laws, let alone to undertake military service, to fight, possibly to die, for one's country. ${ }^{20}$

The natural duty principle only requires that the citizen is conscious that he is part of a polity and that he should (but at no great cost to himself) contribute to its continued existence. Despite its limitation however, Klosko argues that the natural duty principle plays a significant role in the multiple principle theory. ${ }^{21}$ It solves one of the problems of the obligation-to-obey-the-law which is the problem of particularity. On his view, the principle of natural duty solves this problem because it is based on an idea of reciprocity in that, citizens only have natural duties towards their own polity as a result of the benefits they receive from it. Similar natural duties are not owed to other political bodies. Also, in being able to ground obligations that the fairness principle does not account for when combined with the multiple principle theory, the theory is able to cover a wider range of state services. The unification concepts of cumulation and mutual support are here employed to use the natural duty of mutual aid to make up for the limitations of the fair play principle in this regard.

The third principle Klosko employs is the common good principle and it is aimed at accounting for those services that the state provides which though not indispensable to the citizen or aimed at the less fortunate, work to promote the common good of the society. Klosko describes the principle as follows:

The government of society $\mathrm{X}$, which provides indispensable (and necessary discretionary) public goods and basic social welfare services may take

\footnotetext{
${ }^{18}$ KLOSKo, Political Obligations, supra note 2, at 106; Klosko, Multiple Principles, supra note 2, at 808.

${ }^{19}$ Klosko, Multiple Principles, supra note 2, at 809.

${ }^{20} \mathrm{Id}$., at 810 .

${ }^{21}$ KLOSKO, Political Obligations, supra note 2, at 107; Klosko, Multiple Principles, supra note 2, at 810.
} 
reasonable measures to promote the common good in additional ways, with citizens required to do their fair shares to support its efforts. ${ }^{22}$

An appeal to the common good therefore requires that citizens support the state even with relation to services that do not fall into the indispensable or welfare brackets. The principle covers all other state functions to the extent that they promote the common good. Where a service can be seen as addressing a corporate need, even where it is not indispensable to citizens individually it will nevertheless be supportable since it fosters the common good. Klosko gives three conditions that such functions must satisfy in order to come under the common good principle. They are as follows:

(i) the government services or provisions in question must actually be in the public interest; that is, benefits must out-weigh cost;

(ii) the provisions must be distributed fairly; and

(iii) decisions in regard to these benefits must be made democratically, with all individuals having a fair say. ${ }^{23}$

State functions that fall within the common good bracket must possess these features. The state service must be in the interest not of a particular group of persons but of the society as a whole. He refers to these kinds of services as 'common provisions. $^{24}$ They must therefore be seen to be fairly distributed. Where the distribution of the service is not spread out to all or most members of the society, it cannot be said to be aimed at promoting the common good. In addition to substantial 'common-ness' the service must also be procedurally common. It must be based on decisions that are democratically arrived at. Where these features are present, the common good principle applies and will be binding on citizens. However, Klosko concedes that there is no perfect state where these conditions are ideally existent and so these conditions are not required to be strictly satisfied. However, where they are seen to be present in the most part, the duty arising from the common good principle could still be said to be present. ${ }^{25}$

The strength of the common good principle is that it covers a wide range of state services and may even be seen as rendering the fairness and natural duty principles redundant. However, he argues that although the common good principle may seem to overshadow the need for the other two principles and indeed cover similar grounds as the fairness principle, it still stands on its own because of its focus on accounting for those state services that are beneficial to society as a whole as opposed to individual citizens. ${ }^{26}$ Also, the common good principle does not adequately deal with the particularity problem. Although it addresses those services that are beneficial to society as a whole, it does not suggest which society the citizen should support the common good with respect to. However, the fairness prin-

${ }^{22}$ KLosKo, Political Obligations, supra note 2, at 111; Klosko, Multiple Principles, supra note 2, at 813.

${ }^{23}$ KLOSKO, Political Obligations, supra note 2, at 115; Klosko, Multiple Principles, supra note 2, at 815.

${ }^{24}$ KLOSKO, Political Obligations, supra note 2, at 112; Klosko, Multiple Principles, supra note 2, at 813.

${ }^{25}$ KLOSKO, Political Obligations, supra note 2, at 116; Klosko, Multiple Principles, supra note 2, at 814.

${ }^{26}$ KLOSKO, Political Obligations, supra note 2, at 120; Klosko, Multiple Principles, supra note 2, at 814. 
ciple through the concept of reciprocity addresses this and by employing the unification concept of mutual support, is able to make up for this limitation in the common good principle. ${ }^{27}$ In addition, even where it can be successfully argued that the common good principle can also account for presumptively beneficial goods and services by addressing the needs of the less fortunate, in having the fair play and natural duty principles overlap the common good principle with relation to the kinds of state services covered, the multiple principle theory becomes a stronger single ground for the obligation to obey the law.

The multiple principle theory therefore tries to account for three main categories of state functions. First it claims to ground non-excludable goods using the principle of fair play. The duty of fair play arising from the principle precludes persons from free-riding on benefits they have received from the state. Also, it tries to account for state services aimed at addressing the needs of the less fortunate by employing the natural duty principle of mutual aid, in which persons have a natural duty to help others in need. Third, it claims to ground state services that though they do not fall within the first two groups require support from the citizen on the basis that they promote the common good. Where, as in the multiple principle theory, the three principles by virtue of the unification concepts combine, the citizen is under a general and comprehensive obligation to obey the law. The 'comprehensiveness' requirement which applies to the wide range of government functions, can however be seen as derivative of the generality requirement. This is because it seeks to address one of its problematic aspects. It identifies a problem with relation to constructing a general obligation to obey the law which is that the variant nature of the different functions of government calls for a difference in the kinds of arguments that are given to justify support for them. A single argument like fair play cannot be extended to include goods for the less fortunate or common provisions as well as non-excludable goods. In combining these principles, the multiple principle theory is better able to achieve what the independent principles can not. The comprehensiveness requirement can therefore be seen as the structural foundation of the theory. Since the three different principles Klosko identifies cover different types of state functions, combining them can give rise to a single argument for the obligation to obey the law. The multiple principle theory can therefore be seen as a solution to what could be referred to as the 'state functions' problem of the generality requirement. This is because it identifies a particular possible problem with relation to addressing the requirement which is that a theory of political obligation should account for the wide range of services that the state provides.

A theory that only covers a certain kind of state function cannot be said to give rise to a general obligation to obey the law. State functions are social facts. The state in the execution of its aims and objectives tries to provide non-excludable goods, common provisions and cater for the needs of the less fortunate in society. To this extent, the state-functions problem is a factual problem and comprehensiveness, since it relates to covering the wide range of state functions, can be characterised as the factual problem of the generality requirement. A normative problem can also be

\footnotetext{
${ }^{27}$ KLOSKo, Political Obligations, supra note 2, at 113; Klosko, Multiple Principles, supra note 2, at 814.
} 
seen to arise from the generality requirement. This problem deals with the extent to which a theory of political obligation can provide a general motivation to obey the law. The normative problem is based on a distinction between belief and action with relation to the obligation to obey the law. The distinction becomes necessary since obedience to law is an act. This makes belief in the existence of a general obligation to obey the law significantly distinct from a motivation to act according to that belief. In the next section I am going to show how the normative problem is a first-personal problem which arises from asking the question 'why should $I$ obey the law?'

\section{III 'Why Should I OBEy the LAW ?'}

In The Authority of Law, Raz argues that there is no general obligation to obey the law. ${ }^{28}$ While he does not dispute that persons may feel themselves to be under a moral obligation to obey a particular law because of the nature of that law, he doubts that there exists a content-independent obligation to obey all laws. ${ }^{29}$ This obligation would be universal to all laws as opposed to being attached to a particular law. He describes it as follows:

The obligation to obey the law is a general obligation applying to all the law's subjects and to all the laws on all occasions to which they apply. ${ }^{30}$

This is the scope that the generality requirement aims to deal with. ${ }^{31}$ It requires that such an obligation would apply to all laws, all persons in all situations where the law arises. The generality requirement implies asking the question, 'why should I obey the law?' This question can have either or both of two aims. It can have a theoretical or a practical aim. It can be aimed at justifying belief or motivating action. I intend to focus on the practical aim of the question - to motivate action. For this reason, I shall refer to the question, 'why should I obey the law?' 32 as the practical question. The practical question, 'why should $I$ obey the law?' is a firstpersonal question and by virtue of this, has what I shall call first-personal considerations. These are what the first-personal perspective of the question represents the agent as. They are as follows:

\footnotetext{
${ }^{28}$ RAZ, supra note 4, at 233.

${ }^{29}$ Id. at 233-234. On the content-independence of such an obligation, see HLA HART, ESSAYS ON BENTHAM, 265 (1982). Also see EDMUNDSON, supra note 1 at 215, 216.

${ }^{30}$ RAZ, supra, note 4 at 234

${ }^{31}$ Wasserstorm gives a good description of the different forms that political obligation can take of which this form is one. RICHARD WASSERSTORM, The Obligation to Obey the Law in THE DUTY TO OBEY THE LAW 21 (William Edmundson ed., 1999).

${ }^{32}$ The question is used in Thomas Mcpherson, Political Obligation 4 (1967); Peter Singer, DEMOCRACY AND DisOBEDIENCE 6 (1973). Glen Newey discusses other variations of the question in After Politics: The Rejection of Politics in Contemporary LiBeral Philosophy 58-62 (2001). The question is also used in Karen Johnson, Perspectives on Political Obligation: A Critique and a Proposal, 27 WESTERN P. Q. 522-25 (1974); JOHN CARNES, Why Should I Obey the Law?, 71 ETHICS 14 (1960); Edmundson, supra note 31, at 1.
} 
(a) agent as questioner

(b) agent as reflective

(c) agent as actor

I am going to refer to (a) as the referential consideration, (b) as the reflective consideration and (c) as the acting consideration. I intend to discuss them separately with the aim of showing their possible implications for hypothetical responses to the practical question derived from the multiple principle theory.

\section{A The Agent as Questioner}

The practical question indicates that the agent himself is questioning the law's claim to obedience. ${ }^{33}$ The first-person perspective of the question represents the agent himself as the one who is questioning the normative claims of law. I refer to this as law's claims to influence the sphere of action. ${ }^{34}$ The law does not claim to replace reasons for belief but to be a partial or complete substitute for reasons for action. We see a good description of this role of law in practical reasoning as given by Raz. According to his conception, the law claims authority to replace all or most of the reasons for action that persons may have. This does not preclude them from entertaining other reasons. It only precludes them from acting from those reasons. ${ }^{35}$

Lynne Rudder Baker in Persons and Bodies articulates two important features of the first-person perspective. ${ }^{36}$ The first feature is the immunity of the first-person perspective from referential error. The first-person perspective makes it impossible for the user to rightly refer to some other person apart from himself. Where I say for instance, 'I am going to the library', there is little ambiguity as to who I intend to communicate is going to the library. I mean simply that $I$ the maker of the statement is going to the library. ${ }^{37}$ This also means, in addition to reference, that I cannot think of any other person in the first-person way. ${ }^{38}$ The first-person perspective enables me to be introspective and this introspection can only be done by me of myself and not by me of another or by another of me. If for instance Holmes has found the culprit in a murder investigation, I cannot say that $I$ have found the

\footnotetext{
${ }^{33}$ For discussions on law's claim of authority see JOSEPH RAZ, ETHICS IN THE PUBLIC DOMAIN 194 (1994) and RAZ, supra note 4, at 28; PHILlIP SOPER, Legal Theory and the Claim of Authority, 18 PhILOSOPhy P. A. 209-237 (1989); PHILlip SOPER, THE ETHICS OF DEFERENCE: LEARNING FROM LAW's MORALS chapter 3 (2002), and Law's Normative Claims in THE AUTONOMY OF LAW: ESSAYS ON LEGAL POSITIVISM (Robert George ed., 1996) at 215-247; KENT GREENAWALT, CONFLICTS OF LAW AND MORALITY 6, 7 (1967).

${ }^{34}$ Soper gives a different understanding of the normative claims of law. George, supra note 33 at 215247.

${ }^{35}$ This would mean conforming with the law and not complying with it. See JOSEPH RAZ, PRACTICAL REASON AND NORMS 178 (1990).

${ }^{36}$ LyNNe Rudder BAKer, PERSONS AND Bodies: A CONSTITUTION VIEW 69-76 (2000). For more indepth discussions see S. SHOEMAKer, The First-Person PERsPective AND OTHER Essays (1996); KNOWING OUR OWN MINDS (Crispin Wright, Barry C. Smith \& Cynthia McDonald, eds., 1998)

${ }^{37}$ An exception to this is where I am reporting the speech of another with the aim of conveying what was said.

${ }^{38}$ BAKER, supra note 36 , at 71 .
} 
culprit with the aim of communicating that it is Holmes who has found the culprit, without making a false statement. Thus a person cannot refer to someone else in the first person without making a referential error. The significance of the feature of the immunity of the first-person perspective from referential error for the practical question, 'why should I obey the law?' is to establish the agent himself as the questioner. He is identified as the source of the enquiry. He, as the subject of the normative claims of law makes the enquiry calling into question these claims and requiring that a response to the enquiry provide him with reasons to obey the law.

A second feature of the first-person perspective is its relationality. The first-person perspective means that to be conscious of oneself as oneself is to be conscious of oneself as distinct from others. ${ }^{39}$ In other words, being oneself also means not being another or others. To say 'I am happy' is not only to say 'I(myself) ${ }^{40}$ am happy' but also to say 'I(not them) am happy.' In the same vein, when the agent asks, 'why should I obey the law?' he is not only asking 'why should I(myself) obey the law?' He is also asking 'why should I(not them) obey the law?' This second meaning in the question implies that the reasons which apply to others may not be reasons that will apply to him. For instance the response, 'Andrew owns a car' is not an applicable response to Jamie's question, 'why should $I$ own a car?' The response implies that the mere fact that Andrew owns a car is a reason that should be applicable to Jamie. However, the response that will be applicable to Jamie is one which he can act from - one that is his response. ${ }^{41}$ Consequently, the practical question may not be satisfactorily answered by a third-person response. This does not however imply that it would strictly require a first-person response but to argue that in order to act from it, the agent would need to consider the reason in the response as one that could apply to him.

\section{B The Agent as Reflective}

In addition to representing the agent as being the source of the enquiry, the first feature of the first-person perspective also implies that he is conscious of himself as the maker of the enquiry. In asking, 'why should $I$ obey the law?' he is asking, 'why should I (myself) obey the law?' The first-person perspective makes it seem as though there are two referential persons in the question - one who is making the reference and the other of whom the reference is made. It seems to represent the self as constituted by two referential persons, where one referential person is enquiring as to why the other referential person should obey the law. In other words, in asking the question, 'why should $I$ obey the law?' I (the first referential person) is $^{42}$ asking why I (the second referential person) should obey the law. For example

\footnotetext{
${ }^{39}$ Id. at 72

${ }^{40}$ Baker uses 'I*' to represent references to 'I(myself)'. She attributes first usage of this form to Henry Casteneda in He: A Study in the Logic of Self-Consciousness, 8 RATIO 130 (1966); BAKER, supra note 36, at 65 .

${ }^{41}$ Also it can be said that the reasons which Andrew may have for having a car are not reasons that apply to Jamie. I wish to thank Ben Saunders for this further explanation.

${ }^{42}$ I consciously employ the verb 'is' instead of the derivative 'am' with the aim of creating a clearer distinction between the two referential persons.
} 
the statement, 'I am getting old' also implies two referential persons - the one who is getting old and the one who is making the observation that the ${ }^{43}$ other one is getting old. Thus the first-person perspective represents the user not only as the subject of the statement but also as a conscious subject of the statement. ${ }^{44}$ In other words, when using the first-person perspective, in addition to doing or being something, I am also conscious that myself ${ }^{45}$ is doing or being something. Thus the agent in asking the question, 'why should $I$ obey the law?' is not only questioning law's claims, he is also conscious that he is questioning law's claims. He is aware that law makes normative claims and in asking the question, he is distancing himself from those claims. The first-person perspective thus provides the reflective state that enables the agent to stand back from any claim of law and question it. In reflecting in this way, he is reflecting actively and not passively. ${ }^{46}$ This means that the response given should not merely be an endorsive response but a constructive response. It should not be one which takes the following form - 'because I have an obligation to obey the law' in answering the question 'why should I obey the law?' 47 This does not however mean that he should give an agent-relative response but that his response should not simply be an endorsement of the claims of law.

\section{The Agent as Actor}

The first person perspective also shows a distinction between the thinking and acting selves. $^{48}$ This distinction makes the practical question possible. Although the agent, in asking the question, is thinking in order to act, he is at that moment thinking and not acting. ${ }^{49}$ The acting consideration is so called because even though the agent is thinking and not acting, he is thinking in order to act. In asking the practical question, the agent requires not (or not only) a justification for belief but also (and most importantly) a motivation for action. Whereas the thinking self may be satisfied by justification, the acting self requires motivation. This is not intended as a descriptive account of the constitution of persons but to argue that the first-person perspective as a reflective state suggests a distinction between the thinking and acting selves and this distinction makes the practical question possible.

The acting consideration is the most important consideration. This is so because it indicates the main focus of the practical question - what makes it practical. The

\footnotetext{
${ }^{43}$ Here I use the word 'the one' instead of 'the other one' to close the gap between the two referential persons.

${ }^{44}$ BAKER, supra note 36 , at 65.

${ }^{45}$ I use 'myself' instead of 'I' to create a clearer distinction between the two referential persons.

${ }^{46}$ The active/passive distinction is used with relation to questions of moral responsibility. See JOSEPH RAZ, ENGAGING REASON: ON THE THEORY OF VALUE AND ACTION 5 (1999).

${ }^{47}$ Newey in his 'short-cut' theory discusses the problems that can arise from this: NEWEY, supra note 32 , at 66-69.

${ }^{48}$ Not all philosophers of mind and action hold this view. Some take an internalist view to the firstperson perspective in arguing that belief implies action. See Cynthia Macdonald, Self Knowledge and the First-Person in REASONS OF ONE'S OWN, 171-191 (2004) and Externalism and Authoritative Selfknowledge in Wright et al, supra note 36, at 123.

${ }^{49}$ We characterise action in a strict and not general sense which could include thinking as a form of acting.
} 
purpose of the question is to inform the agent as to action. Most of the arguments given in favour of the existence of a general obligation to obey the law make an internalist assumption - that a justification of belief would motivate action. ${ }^{50}$ In the practical question, I take an externalist view of the problem of political obligation which is that the justification of belief and motivation for action give rise to different considerations and a motivation for action is most important with relation to the duty to obey the law. This is because obedience to law is an act or a series of acts. Thus, where an argument justifies belief but does not motivate action, it fails to be an adequate response to the practical question.

Some clarifications are however necessary. First is that the acting consideration deals with two senses in which the term 'act' can be used with relation to the practical question. The first sense is the act which forms part of a context from which the practical question could arise. Thus the agent may ask, 'why should I obey the (traffic) law?' In this example, complying with traffic rules is the legally-required act. The act is internal to the context. The second sense in which 'act' is used is where the context as a whole is characterised as an act of obedience to law. The importance of this differentiation can be defended using Raz's distinction between complying and conforming with the law. The distinction can be explained as follows: when I do a legally-required act mainly or purely for other reasons apart from the fact that the law requires it, I am conforming to the law. But I comply with the law when I do the act because or principally because the law requires it. Although in both cases I do the act which the law requires, they both give rise to different meanings and implications. Whereas in the first case I am not motivated by the law but still do what it requires, in the second case I am motivated (absolutely or principally) by the law itself and not the required act. Only the second case constitutes obedience to law - where I am acting from the law. The acting consideration is primarily concerned with the meaning of the act in the second case. The question is taken to address law's general claim to influence the sphere of action. Thus even though obeying the law mainly requires doing a specific act or a series of acts, the peremptory and content-independent nature of the kind of obligation sought for requires that emphasis be laid on the act-of-obedience-to-law and not the specific acts themselves. Thus whereas obedience to law may imply performance of specific acts or series of acts, the act of obedience to law is what is relevant to the universality criterion.

A second clarification is with relation to the kind of motivation that is required in the criterion. The kind of obligation defined by the universality criterion is one that applies to 'all the law's subjects and to all the laws on all occasions to which they apply. ${ }^{51}$ This is what makes it a general or a universal obligation because it cuts across the specificity of laws or the specificity of situations. This general obligation to obey the law can be seen as entailing two things - a general belief that one is

\footnotetext{
${ }^{50}$ For more discussions on internalists and externalists see Internal and External Reasons in BERNARD Williams, MORAL LUCK (1981); CHRISTINE KORSGAARD, Kant's Analysis of Obligation: The Argument of Groundwork 1 and Skepticism about Practical Reason, both in CHRISTINE KorSGAARD, CREATING THE KingDOM OF ENDS 43, 311 (1996).

${ }^{51}$ RAZ, supra note 4, at 234.
} 
under a duty to obey the law and a general motivation to act in compliance with that belief. The general nature of the obligation is mainly with relation to the level of its attachment and not its stringency. In other words, the general obligation described in the requirement is not intended to imply an absolute but a prima facie obligation. $^{52}$ This is one that can be outweighed by stronger considerations. The main thrust of the universal nature of the universality criterion is with relation to its 'detachment' from particular situations and laws. It is not an attachment to particular laws but an attachment to the 'all-ness' of laws that is entailed. Thus the universality criterion is not satisfied by a specific motivation - one that arises as a result of a particular situation or with relation to a particular law; but one that is attached to all or most laws in all or most of the situations in which they arise. ${ }^{53}$ My interest however is not to give a psychological account of the dynamics of motivation or an account of how motivation may feature in our practical reasoning. ${ }^{54}$ I will rather be primarily concerned with trying to define what a general motivation to obey the law would require in order to be achieved. In other words, what it would mean for hypothetical responses derived from the multiple principle theory. The definition will particularly be in terms of what is required in a theory to ground a general motivation to obey the law.

I argue that where there are elements that must exist or conditions that must be fulfilled, in order for the advanced argument for a general obligation to obey the law to be successful, and these conditions do not exist in all or most of the situations in which compliance to legal rules is required, the argument would fail to support a general motivation to obey the law in compliance with the argument. In other words, whereas an argument for the existence of a duty to obey the law may be plausible and so satisfy the belief-requirement for the existence of such an obligation, where there exist conditions for its success, these conditions need to exist in all or most of the time in order to support a general motivation to obey the law in compliance with the argument. This is not to say that in every case where the conditions exist, the agent does in fact obey the law but to say that with relation to plausible arguments, the existence of conditions on which an argument is based would generally motivate persons to act in compliance with the argument. For instance we can see this in the fair play principle, where persons in a cooperative scheme who benefit from the joint efforts of members of the scheme are under a duty of fair play to contribute to the continued existence of the scheme and not to

\footnotetext{
${ }^{52}$ Prima facie obligations as introduced by Ross are of less stringency. However, the account adopted by political philosophers is slightly but non-significantly different from the original model advanced by Ross. DAVID Ross, The Right AND THE GOOD 16-47 (1932); MBE SMITH, Is There a Prima Facie Obligation to Obey the Law?, 82 YALE L. J. 950 at 951, 952 \& 970 (1973); MATTHEW KRAMER, Legal and Moral Obligation, in THE BlackWell Guide to THE PhILOSOPHY OF LAW AND LegAL THEORY 179-80 (2005).

53 This may solve the 'moral force' problem which Klosko identifies as a problem of the generality requirement. A strict understanding of the requirement makes no distinction between the moral force of a particular law and that of other laws. See George Klosko, The Moral Force of Political Obligations, 84 AMERICAN P. S. REV., 1237 (1990).

${ }^{54}$ General discussion on this can be found in G.R. GRICE, Motive and Reason, in PrACTICAL REASONING 168-177 (1978).
} 
free ride. ${ }^{55}$ This argument can appeal even to the hardest egoist. Where there is a cooperative scheme and A benefits from the joint efforts of B, C and D, A is under a duty to 'do his share' in the scheme. It is largely uncontentious that this duty arises from the scheme and can only be overridden by stronger considerations. In order words, A is required to have a stronger reason not to participate in the scheme - a scheme from which he benefits. Where the features of this kind of cooperative enterprise exist, persons are therefore arguably under a prima facie obligation to contribute to it.

Out of the three considerations (referential, reflective and acting), only one has significant implications for a response to the practical question 'why should I obey the law?' The response should give rise to a general motivation to obey the law of the kind described. Although I have discussed the referential and reflective considerations alongside the acting consideration, a response will not be required to satisfy the first and second considerations. To require that a derived response satisfy these two considerations would amount to over-stretching the use of the first-person perspective because the arguments are not formulated as responses to a question. The only consideration requiring to be satisfied and which in itself is fundamental to the universality criterion, is the acting consideration requiring that an argument provide a general motivation to obey the law. Thus, though in the consideration of the derived responses the extent to which they meet the requirements of the referential and reflective considerations will be considered, it will not be significant whether these requirements are met. It is only significant to the enquiry that the hypothetical responses satisfactorily address the requirements of the acting consideration - that they ground a general motivation to obey the law.

\section{Hypothetical RESPONSES}

Now let us look at possible hypothetical responses to the question, 'why should I obey the law?' from the multiple principle theory. The fair play principle in stating that persons are under a duty to contribute to schemes from which they have benefited suggests that its possible response to the practical question would be 'because I have benefited from the state and should do my share to support it.' The response implies a reliance on the reception of benefits as sufficient to attract a duty of fair play. This focus distinguishes Klosko's version of the principle from that advanced by Hart and Rawls. For them, the existence of a cooperative scheme as the origin of the benefits received is significant in the fair play principle. This would distinguish an innocent bystander from a participant with reference to the enterprise since there could be a question as to whether similar requirements should be made from persons who are merely caught within the operation of the scheme and are not

\footnotetext{
${ }^{55}$ The fair play account was first articulated by Hart and then further developed by Rawls. Other versions of the theory have been given by Simmons and Klosko. Hart, supra note 8; Rawls, supra note 10; John Simmons, Moral Principles and Political Obligation, 101-142 (1979); George Klosko, The Principle of FAirness and Political Obligation (1992). Also see MatTheW KRAMER, IN DEFENSE OF LEGAL POSITIVISM: LAW WITHOUT TRIMMINGS 254-388 (1999).
} 
involved in conducting it. ${ }^{56}$ However, Klosko's version seems to avoid this problem by making the reception of benefits sufficient to bring persons under a duty to contribute to the scheme. ${ }^{57}$ This version particularly covers the reception of presumptively beneficial goods since persons benefit from them whether or not they are part of or indeed aware of the 'scheme' that provides them. The reception of benefits can therefore be seen as a condition in Klosko's version of the principle.

Where persons have not taken advantage of presumptively beneficial goods, then the duty does not arise. The fair play argument seems plausible as it could be argued that one owes a duty to oneself to assist in the continued existence of a scheme from which one receives benefits which are indispensable to living a worthwhile life. The argument therefore satisfies the 'belief-requirement' because it is an argument that persons would generally find plausible. However the acting consideration places a further standard - that persons are generally motivated to act according to this belief. Such a general motivation would be interpreted as being existent where the condition on which the argument relies on for its plausibility exists all or most of time. The presumption is that where this is so, persons would be generally inclined to obey the law following the argument. The question is therefore whether the reception of benefits attracting the duty of fair play occurs all or most of the time. This would require certainty as to the provision of presumptively beneficial goods by the state. Goods such as protection or the rule of law must be seen as certain to be received in order to motivate the citizen to act from a duty of fair play in all or most situations where a legal requirement arises. However, even in societies that are regarded as highly democratic and efficient, goods such as the rule of law or protection cannot be said to be guaranteed goods. The aim of even the most democratic and efficient state is to be committed to making sure that these goods are available to its citizens. Making a further claim that it does in fact make these goods available most or all of the time would be a claim too strong to make. This problem could indicate that the duty of fair play based on the provision of non-excludable goods, would not give rise to a general motivation to act according to the duty because of the uncertainty of the provision of these goods.

The principle of mutual aid unlike the fair play principle does not arise because persons have benefited from the state's provision of presumptively beneficial goods. For the principle of mutual aid as a natural duty variant, the only requirement is to be human. A possible response to the practical question from this principle could therefore simply be 'because I should assist less fortunate persons.' The response is aimed at covering state services that cater for the less privileged in society. It can be seen to rely on two elements. First the existence of less fortunate persons and second the existence of government policies and programmes addressing their needs. The principle as characterised by Klosko does not seem to require that these policies and programmes actually adequately address the needs of less fortunate persons. It only requires that there exists a government commitment

\footnotetext{
${ }^{56}$ SIMMONS, supra note 55, at 120.

${ }^{57}$ KLOSKO, Political Obligations, supra note 2, at 39-54; Klosko, Multiple Principles, supra note 2, at
} 804. 
towards the plight of the less fortunate and this commitment is sufficiently evidenced by the existence of policies and programmes to this end. Thus, the principle is aimed at grounding the citizen's support for the efforts of government towards less privileged persons.

With relation to the acting consideration these two elements which can be regarded as conditions, the existence of which the principle relies on, can feature in most situations in which a legal requirement arises. It can be said that since most if not all societies suffer imbalances in the distribution of resources, there are always persons who will have less than others - indeed who will have less than they need to carry on a worthwhile life. Therefore these persons and their needs will always be the concern of a responsible government. Following the principle, citizens therefore should obey the law in support of government efforts towards the less fortunate in society. But on Rawls' characterisation of the principle of natural duty, on which principle Klosko derives the duty of mutual aid, the duty is not one that should be followed through by the citizen at great cost to himself. ${ }^{58}$ Therefore where obeying the law in a particular circumstance would be at a great cost the citizen can choose not to obey. Thus, whereas the duty of mutual aid can provide a general motivation to obey the law to the extent that its conditions are almost always in existence, the nature of its stringency makes it independently inadequate and therefore reliant on other more stringent principles in the theory.

The common good principle is aimed at covering all other state services that do not fall under the categories of non-excludable goods and goods for the less fortunate. This is provided that they serve to promote the common good of the society. Since it is in the interest of the citizen that the state as a whole continues to function, a state service, though not indispensable to him or directly aimed at the less fortunate, would still require the citizen's support, if it was for the good of the society as a corporate unit. A possible response to the question 'why should I obey the law' drawn from this could thus be 'because I should do my share to promote the common good of the society.' However for the common good principle to apply, its conditions as suggested by Klosko must be satisfied. First for a state provision to be regarded as being in the common good, it should be in the public interest. Klosko interprets this as being that 'its benefits should outweigh its costs." ${ }^{59}$ These provisions must also be fairly distributed among members of the society. Also, decisions on these provisions should be democratically made. Klosko however does concede that these conditions may not be perfectly achievable in the real world.

Even where democratic procedures are obtainable, these procedures may be abused. In the absence of safeguards, the majority would always have their way at the expense of the minority. ${ }^{60}$ This could affect the first condition - fair distribution,

\footnotetext{
${ }^{58}$ JOHn RAWLS, A THEORY OF JUSTICE 114 (1999); KLOSKO, Political Obligations, supra note 2, at 105 Klosko, Multiple Principles, supra note 2, at 804.

${ }^{59}$ KLOSKO, Political Obligations, supra note 2, at 105; Klosko, Multiple Principles, supra note 2, at 804.

${ }^{60}$ KLOSKO, Political Obligations, supra note 2, at 115; Klosko, Multiple Principles, supra note 2, at 815.
} 
where the principles guiding the fair distribution of the provisions are required to be the product of democratic procedures. Klosko suggests however, that the nature of democracy is such that any such decisions which are the product of abuse of democratic procedure can almost always be revisited. ${ }^{61}$ There is therefore a likelihood that they may be changed and any such abuse corrected. The third condition is therefore aimed at protecting the citizen in his support for the provision of common goods. ${ }^{62}$ The 'common-ness' of the goods has substantive and procedural requirements. In addition to the substantive requirements of being in the public interest and being fairly distributed, decisions relating to such goods must also meet the procedural requirement of being reached democratically. The conditionelement for the principle is therefore composed of these three requirements. The principle is based on the existence of state services that fulfil these substantive and procedural requirements. Where such state services exist, a duty to obey the law derived from the common good principle arises. However with relation to the acting consideration, there are two questions that become relevant. They are:

(a) To what extent do state services meet these requirements?

(b) To what extent do they meet these requirements all or most of the time?

These are similar but distinct questions. While the first requires only that it is shown that the requirements of the common good principle are met, the second question requires that these requirements are shown to be met in all or most situations in which obedience to a legal rule could arise. In democratic societies the second and third requirements as given by Klosko are part of the accepted political culture. Decisions are generally expected to be made through democratic methods and except where there are justified considerations to the contrary, resources are expected to be fairly distributed. The aim of such a culture is to achieve justice. However even where substantive justice is not achieved, the existence of these procedures and the commitment of the state towards sustaining them should be sufficient to show that a state is democratic. It would be unrealistic to require that every product of the wielding of democratic machinery would attain the standards of substantive justice. And indeed not every democratically made decision is just. But since procedural standards are sufficient, it can be said that the acting consideration is satisfied because democratic procedures are almost always followed in democratic societies. However with relation to the common good principle, Klosko suggests higher standards. He says,

... but we should recognize that CG does not justify all government enactments that purport to be in the public interest. The principle legitimizes only those that actually promote the common good. ${ }^{63}$ (Emphasis supplied)

This means that with relation to the common good principle, only substantive standards are sufficient if the principle is to ground any moral claims on persons. In

\footnotetext{
${ }^{61}$ KLOSKO, Political Obligations, supra note 2, at 117; Klosko, Multiple Principles, supra note 2, at 817.

${ }^{62}$ KLosko, Political Obligations, supra note 2, at 118; Klosko, Multiple Principles, supra note 2, at 817.

${ }^{63}$ KLosko, Political Obligations, supra note 2, at 116; Klosko, Multiple Principles, supra note 2, at 816.
} 
other words, the goods provided must actually be in the public interest to place duties on citizens. While it may largely not be contentious to say that even in the least democratic state, there could be evidence of state provisions that are actually in the common good (thereby favourably addressing the first question) it would be more difficult to make similar claims with relation to the second question even in the most democratic state. Not all or most common provisions eventually actually promote the public interest. The best that can be said for them is that they are intended to do so and decisions on them are democratically arrived at thus fulfilling procedural standards. If substantive standards are to ground a general motivation to obey the law arising from the provision of common goods then these goods must be seen by the citizen to be almost always or in the most part actually beneficial to the whole society.

The multiple principle theory can be understood in two ways. It can be understood as requiring the citizen to support the specified categories of state services (that is presumptively beneficial goods, goods for the less fortunate and common provisions) because these categories give rise to certain species of obligations or it can be understood as requiring the citizen to support a government that is committed to providing and/or actually does provide the three specified types of goods. The second understanding would suggest that the theory indirectly tries to give an account of what a good government should be like with the aim of justifying a duty to support such a government. The theory can then be understood as a single 'super-duty' composed of three reasons for obedience to law. However if the three reasons are to be characterised as working in tandem to cover all or most of the possible situations where a legal rule could arise then the first understanding of the theory seems more apt. It could imply that each situation would require an applicable reason chosen from the three given reasons. ${ }^{64}$

With this understanding it would therefore seem that the requirements of the acting consideration are satisfied - where every situation would have an applicable reason. However if all the situations in which a legal rule could arise are divided into the three categories of goods, and within a group, the occurrence of the conditionelement for the principle is not sufficient to ground a general motivation to obey the law, it would leave many situations within the group uncovered. Since within the groups that the principles aspire to cover, the coverage (which though sufficient to ground a belief in the principle is not sufficient to ground general action from the principle), the coverage is not sufficient to be general, and even when cumulatively considered they cannot be said to offer a general coverage, within the meaning of comprehensiveness. The effect of the combination in the multiple principle theory is that it would provide more coverage than the principles could have achieved independently. However, their independent limitations with relation to the acting consideration still affect the possible coverage of the theory in grounding a general motivation to obey the law. Thus even where it can be said that the three hypo-

\footnotetext{
${ }^{64}$ It could be argued that this interpretation could have the implication of flying in the face of the generality requirement since the nature of the specific law would then be significant with relation to the obligation to obey the law.
} 
thetical responses satisfy the referential and reflective considerations - in that they are arguments that the agent could perceive as applying to him on one hand and represent him as not un-reflectively endorsing the claims of law on the other; in failing to satisfy the acting consideration by giving rise to a general motivation to obey the law, the fair play and common good responses cannot be considered an appropriate responses to the practical question, 'why should I obey the law?' The same applies to the natural duty response, which though satisfying the acting consideration lacks the stringency to independently cover all three categories of state goods without the aid of the other principles.

It could be objected that the natural duty response does not show active reflection as it is a duty that arises non-volitionally. However, in order to act from such a duty, the agent must accept that it applies to him. This acceptance means reflective activity and not passivity. Also reflective passivity within the meaning of the reflective consideration relates to an endorsive response to the claims of law as opposed to an argument justifying the claims of law. In other words, while direct endorsement of the claims of law would entail passive use of reflection, indirect endorsement through the endorsement of an argument justifying those claims entails rather an active use of reflection. Therefore reflective endorsement in itself is not passivity. ${ }^{65}$ It is only passivity where normative claims are directly accepted in the absence of reasons. Reasons reflect reflectivity.

A further problem could arise concerning the relationship between reflective acceptance and the referential consideration. The problem is with relation to distinguishing between using the expression ' $\mathrm{I}$ ' as it relates to active or passive reflection. To clarify this ambiguity we employ the use of the notion of priority. The reflective consideration is prior to the referential consideration and so plays a regulatory role with relation to it. In other words, only responses that satisfy the reflective consideration are appropriately referential. It is only when persons are reflecting actively that a communication of the activities of 'I' are genuine. For instance in making the statement, 'I want to go to the cinema' the speaker is trying to communicate that he has personal reasons for choosing to go to the cinema. The statement would however be a not very precise representation, if the speaker was told by another person (by command or request) to go to the cinema. In this circumstance the statement, 'I have been told to go to the cinema' would be a more precise representation. In the same vein an endorsive response to the claims of law in the manner 'because I have an obligation to obey the law' could be an ambiguous representation of whether the speaker believes she has such an obligation or whether she is simply accepting what she has been told. The referential use of 'I' here can be construed as being precise or imprecise. However the use of the first-person expression is more precise when used to communicate reflective activity, hence the reflective consideration being prior and therefore regulatory to the referential consideration.

\footnotetext{
${ }^{65}$ Here I refer particularly to a Kantian account of reflective endorsement, as given by Christine Korsgaard. CHRISTINE KORSGAARD, THE SOURCES OF NORMATIVITY 50, 89 (1996).
} 


\section{CONCLUSION}

The multiple principle theory as composed by the three hypothetical responses does not adequately address the first-personal considerations of the question, 'why should $I$ obey the law?' Although the fair play and common good principles can be seen as satisfying the referential consideration by being responses that persons could give on one hand and address the reflective consideration on the other by representing persons as reflective in not simply endorsing the claims of law, they do not give rise to a general motivation to the agent to obey the law. This is because the condition-elements on which they rely do not exist all or most of the time which would be sufficient to ground a general motivation to obey the law. Also, the natural duty response while satisfying the acting consideration lacks the stringency to independently cover all three categories of state goods with relation to general motivation without the aid of the other principles. A first-person perspective analysis of all three responses that make up the multiple principle theory shows the significance of a distinction between action and belief with relation to the question 'why should I obey the law?' 